\title{
Socioeconomic Study of Grasses and Legumes in Baria and Godhra Forest Division, Gujarat
}

\author{
Dhara J. GANDHI, Susy ALBERT**, Neeta R. PANDYA, Krishna R. PANCHAL \\ The Maharaja Sayajirao University of Baroda, Faculty of Science, Department of Botany, Vadodara- \\ 390 002, Gujarat, India; drsusyalbert@rediffmail.com (*corresponding author)
}

\begin{abstract}
Gujarat has rich traditional knowledge associated with biodiversity. The cultural diversity in the Indian society reflects close relationship between the existence of human life and nature including all other living creatures and non-living creatures. The present paper deals with the traditional knowledge of villagers in 10 villages nearby the grasslands in Panchmahal and Dahod districts of Gujarat, India, regarding the multipurpose use of grasses and associated legumes prevailing in these grasslands. A survey with the help of questionnaire was conducted to analyze the socioeconomic status. 69 grass species and 34 legumes could be identified growing in these grasslands of which 92 were used for livestocks. Among these grasses the most preferred grass species were Dichanthium annulatum and Sehima nervosum because of its high palatability. Three grasses and 8 legume species were used for food and medicine. The study emphasizes the use of plant wealth to human needs of the regions and assist in appraisal of various anthropogenic interventions accountable for loss of prevailing biodiversity of the region.
\end{abstract}

Keywords: Baria, grasses, Godhra, legumes, socioeconomic

\section{Introduction}

Socio-economics is the study of the relationship between economic activity and social life. The field is often considered multidisciplinary, using theories and methods from sociology, economics, history, psychology, and many others. It has emerged as a separate field of study in the late twentieth century. In many cases, however, socio-economists focus on the social impact of some sort of economic change.

Forest is both ecological as well as economic resource. Forests are home to $50-90 \%$ of earth's species and are potentially renewable resources if used as per optimum needs and ensuring their security as per sustainability. The functions of a forest may be broadly classified into three categories protective, productive and regulatory functions (Mishra et al., 2008). The socio-economic conditions, the poverty, the illiteracy, unemployment and under employment prevalent in the villages adjoining to the forest forced the people to use the resource as economic resource and never gave an opportunity to think of ecological relevance of the resource in the area. Efforts by the forest department to protect the resource in isolation resulted into conflicts with the locals and more damage to the forest resource leading to the degradation of the land resources.

The contribution of uncultivated wild plants for livelihood support will depend largely on individual circumstances (FAO, 1999). The grassland biome which includes a wide range of ecosystem types from humid priaries to arid shrub grass steppes, has been subjected to particularly intense pressure for the production of food and fibres
(Gandhi et al., 2010). These plants can provide an opportunity for cash generation. Value addition may be possible to the collected uncultivated foods if they are processed into edible foods prior to the scale.

Many wild plants have significant economic value. By preventing the need for cash expenditure, and income derived from the collection and sale of these resources is particularly important for the rural poor as a source of cash. Some wild plants are important elements for regional identity.

Gujarat state harbors nearly 4,320 plant species which accounts for almost $9.33 \%$ of the total floral wealth of India (Agrawal, 2001). The tribals in the state use about 750 medicinally important and 450 economically important plant species. The eastern part of Gujarat has been exclusively studied with respect to ethanobotanical and medicinal values of various plant species (Gopal, 1983; Parabia et al., 1978; Reddy, 1986). More than 61 million people of different ethnic groups following varied religious beliefs live in the Gujarat state, which accounts for $14 \%$ of state population. Tribal populations of Bhil, Dhodiya, Kolcha, Koli, Konkni, Gond, Gamit, Valvi, Talvi, Padhar, Pateliya, Rathava, Siddi, Waghri, etc. spread over 8 districts, predominantly inhabit the forest areas all along its Southeastern boundary. These tribal people mainly depend on forest for their shelter, housing material, food, fuel, fiber and feed. Traditional knowledge accumulated generations to help peoples protect their nutrition and health and manage their habitats (Olsson et al., 2004). The possibility that traditional knowledge may be rapidly and widely lost in response to globalization has become a major concern 
54

of scholars and policy markers (Agrawal, 2002; Sillitoe, 1998).

Grasslands play an important role in performing ecological functions including the maintenance of biodiversity. They help in maintaining humus in the soils which paves the way for establishment of tree forms (Tyagi, 2010). In Gujarat grasslands cover an area of about 8490 $\mathrm{Sq} \mathrm{km}$. It can be divided into 5 major regions (Dabadghao and Shankamarayanan, 1973). Socioeconomic survey and ethanobotanical studies indicate that the tribals in these forest areas are mainly dependant on the resources from these areas for their livelihood. In our three years survey in collaboration with the forest department we could see that the grasslands had grasses associated with specific legumes. Legumes are one of the largest and most valuable groups of flowering plants. It was thought worthy to understand the economic importance of these plants in the grasslands.

Grasses and herbaceous legumes majorly found in the wild are harvested or collected from natural and semi-natural environment for the purpose of human use. Grasses are one to the largest and most valuable groups of flowering plants, consisting of some 610 genera and about 10,000 species (Cope and Poaceae, 1982). Clayton and Renvoize (1986) put the total number of grasses in the world about $10,000 \mathrm{sp} .651$ genera were recognized and assigned numbers indicating their phylogentic status based upon various evidences (Clayton and Renvoize, 1986). It ranks third in number of genera after the Compositeae and Orchidaceae, Leguminoseae and Rubiaceae (Good, 1953). Grasses are widespread than any other family of flowering plants. The great adaptability of different species has enabled them to thrive under the most varied conditions (Ahmad et al., 2009). Grasses exceed all other in the importance of its products. It provides food in the form of cereals for man and forage for most animals. There can be no doubt that cereal and pasture grasses are economically the most important plants in the world, and it would be quite impossible to imagine how mankind could continue agriculture without them.

The purpose of the socioeconomic study was to document the multiple uses of the grasses and associated species especially the legumes present in the some grasslands of Baria and Godhra in Panchmahal and Dahod districts of Gujarat.

\section{Material and methods}

The present study is the outcome of critical minute and systematic study of grasses and legumes associated with these and their uses by the tribal people of the area. The study area covers 10 villages adjoining grasslands of Baria and Godhara selected by random sampling method. Total 12 field trips were conducted in the ten selected villages throughout the study period. Field visits were arranged at an interval of one month beginning from June 2009 to January 2010 in all the representative localities of the area. The growth period of grasses was at its peak during September to December, during which the field visit was conducted at an interval of 15 days. A map of the area with the important places of data collection is given (Fig. 1). Grasses and legumes associated to these grasses were collected during the field trips. Detailed morphological features were noted down of the plants with the help of dissecting microscope and identified with the help of different floras (Cook, 1903; Shah, 1978; Blatter and McCann, 1936). Plant specimens were also collected for preparation of herbarium. Prepared herbariums were confirmed with the voucher specimen at Blatter Herbarium, Mumbai.

Randomly 7 villages from Baria Forest divisions (Rampur, Jekot, Kharoda, Kantu, Bhey, Rozam, and Kali talai) and 3 from Godhara Forest division (Segva, Bakkhar, Samli) were included in the present study.

A questionnaire (Proforma 1) was prepared for collection of useful information regarding the local uses of the grasses and associated legumes growing in the nearby grasslands. From the data available with the forest department and local people, information about the different

\section{PROFORMA 1}

Source / Village Range :

Total House holds : Total Population :

Area :

\section{Different Tribes with their House Holds:}

$\begin{array}{ll}1 . & 6 . \\ 2 . & 7 . \\ 3 . & 8 . \\ 4 . & 9 . \\ 5 . & 10\end{array}$

\section{$\begin{array}{ll}\text { 1. Species Name : } & \text { 2. Local Name : }\end{array}$}

3. Medicinal Use :

4. Part used and its Method :

5. Other Use :

Ecological Use :

Economical Use :

\section{Season of collection :}

\section{Stage of collection}

8. Palatable or not :

\section{Fodder for which animals :}

10. Fodder value : 


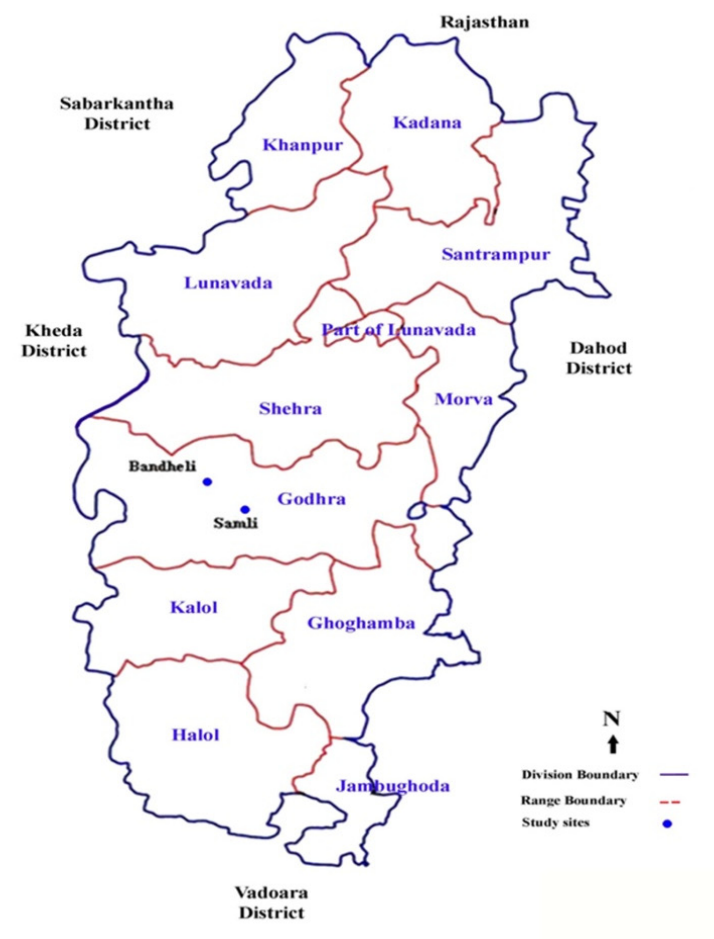

MAP - I SHOWING

POSITIONS OF STUDY

SITES IN GODHRA

FOREST DIVISION

\section{MAP - II SHOWING POSITIONS OF STUDY SITES IN BARIA FOREST DIVISION}

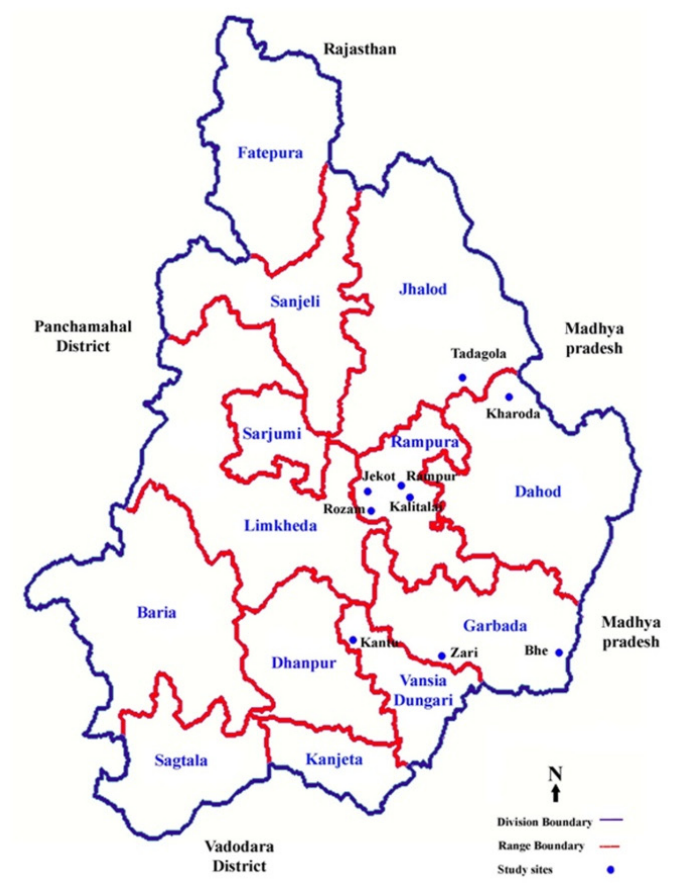

Fig. 1. Map of the area with the important places of data collection

tribal blocks existing in Baria and Godhara division was collected and the socioeconomic survey conducted including population from each tribe. A face to face interview was conducted among randomly selected $10 \%$ households from each community tribals from these villages. The questionnaire attempted to elicit information about the plant species in the grassland being used medicinally, ecologically and economical. Social customs, traditional knowledge and nature and extent of dependency on the forest by the tribals were tried to be evaluated. The method of grass collection and storage and the fodder value has been assessed.
Survey of the diversity of grasses and legumes growing in the grasslands nearby the village have been noted down.

\section{Results and discussion}

A list of the tribes located in the 10 different villages has been represented in Tab. 1. The Bhakkhar village in Godhra range, has highest amount of population with the highest number of house hold (i.e. 950 household), while Segva has the least population. In the Rampur range, Kalitalia village occupies the largest area but the population 
Tab. 1. Distribution of the different tribes in the selected villages

\begin{tabular}{|c|c|c|c|c|c|c|c|c|c|c|c|c|c|c|c|c|c|c|c|c|}
\hline & \multicolumn{6}{|c|}{ Range-Godhara } & \multicolumn{8}{|c|}{ Range-Rampura } & \multirow{2}{*}{\multicolumn{2}{|c|}{$\begin{array}{c}\text { Range-Dahod } \\
\text { Kharoda }\end{array}$}} & \multirow{2}{*}{\multicolumn{2}{|c|}{$\begin{array}{c}\text { Range-Garbada } \\
\text { Bhe }\end{array}$}} & \multirow{2}{*}{\multicolumn{2}{|c|}{$\begin{array}{c}\text { Range-Vasia Dundr } \\
\text { Kantu }\end{array}$}} \\
\hline & \multicolumn{2}{|c|}{ Segva } & \multicolumn{2}{|c|}{ Samli } & \multicolumn{2}{|c|}{ Bakkahr } & \multicolumn{2}{|c|}{ Kalitalai } & \multicolumn{2}{|c|}{ Jekot } & \multicolumn{2}{|c|}{ Rozam } & \multicolumn{2}{|c|}{ Rampur } & & & & & & \\
\hline Total House Hold & \multicolumn{2}{|c|}{437} & \multicolumn{2}{|l|}{500} & \multicolumn{2}{|c|}{950} & \multicolumn{2}{|c|}{220} & \multicolumn{2}{|c|}{350} & \multicolumn{2}{|c|}{401} & \multicolumn{2}{|c|}{172} & \multicolumn{2}{|c|}{1450} & \multicolumn{2}{|c|}{275} & \multicolumn{2}{|c|}{100} \\
\hline Total Population & 150 & & 5000 & & 500 & & 12 & & 240 & & 208 & & 128 & & \multicolumn{2}{|c|}{11461} & \multicolumn{2}{|c|}{5619} & \multicolumn{2}{|c|}{1800} \\
\hline Total Area & \multicolumn{2}{|c|}{ 985ha } & \multicolumn{2}{|c|}{$790 \mathrm{ha}$} & \multicolumn{2}{|c|}{859 ha. } & \multicolumn{2}{|c|}{$1368 \mathrm{ha}$} & \multicolumn{2}{|c|}{$999.46 \mathrm{ha}$} & \multicolumn{2}{|c|}{$759 \mathrm{ha}$} & 572 & & 183 & 7 ha & & & & \\
\hline $\begin{array}{l}\text { Different Tribe with } \\
\text { their House Hold }\end{array}$ & Tribe & No. & Tribe & No. & Tribe & No. & Tribe & No. & Tribe & No. & Tribe & No. & Tribe & No. & Tribe & No. & Tribe & No. & Tribe & No. \\
\hline 1 & Baria & 382 & Baria & 250 & Baria & 400 & ST & 220 & $\mathrm{OBC}$ & 66 & Adivasi & 389 & Savarn & 24 & ST SC & 1450 & SC & 109 & Adivasi & 99 \\
\hline 2 & Raval & 1 & Rajput & 40 & Patel & 300 & & & SC & 4 & $\mathrm{OBC}$ & 8 & ST & 148 & & & ST & 168 & patel & 1 \\
\hline 3 & Muslim & 9 & Muslim & 10 & Muslim & 1 & & & ST & 280 & Pateliya & 4 & & & & & & & & \\
\hline 4 & Nayak & 45 & Vadand & 7 & Nayak & 75 & & & Savarn & 7 & & & & & & & & & & \\
\hline 5 & & & Harijan & 30 & Vadi & 4 & & & & & & & & & & & & & & \\
\hline 6 & & & Vankar & 140 & Vankar & 5 & & & & & & & & & & & & & & \\
\hline 7 & & & Brahmin & 1 & Navi & 65 & & & & & & & & & & & & & & \\
\hline 8 & & & Rathava & 22 & Vanzara & 80 & & & & & & & & & & & & & & \\
\hline 9 & & & & & Malivad & 25 & & & & & & & & & & & & & & \\
\hline
\end{tabular}

OBC-Other Backward Class; ST-Schedule Tribe; SC-Schedule Class 
Tab. 2. List of Palatable Grasses

\begin{tabular}{|c|c|c|c|c|}
\hline \multirow{2}{*}{$\begin{array}{l}\text { Sr. } \\
\text { No. }\end{array}$} & \multicolumn{3}{|c|}{ Palatability } & \multirow{2}{*}{ Unpalatable } \\
\hline & High & Moderate & Low & \\
\hline 1 & Bothriochloa pertusa (L.) A. & Andropogon pumilus Roxb. & Apluda mutica L. & Aristida adscensionis $\mathrm{L}$ \\
\hline 2 & Cenchrus ciliaris $\mathrm{L}$. & Arthraxon lanceolatus (Roxb.) Hochst. & $\begin{array}{l}\text { Cymbopogon martinii } \\
\text { (Roxb.) Wats. }\end{array}$ & $\begin{array}{l}\text { Aristida funiculata Trin. } \\
\text { and Rupr. Sp. Gram. }\end{array}$ \\
\hline 3 & Chrysopogon fulvus (Spr.) Chiov. & Bracharia cruciformis (J.E. Sm.) & $\begin{array}{c}\text { Melanocenchris } \\
\text { jaequemontii J. and S. }\end{array}$ & $\begin{array}{l}\text { Desmostachya bipinnata } \\
\text { (L.) Stapf }\end{array}$ \\
\hline 4 & Coix lachryma-jobi L. & $\begin{array}{l}\text { Bracharia reptans (L.) } \\
\text { Gard. and C.E. Hubb. }\end{array}$ & $\begin{array}{l}\text { Oplismenus burmannii } \\
\text { (Retz.) P. Beauv. }\end{array}$ & Dinebra retroflexa (Vahl) Panz. \\
\hline 5 & Cynadon dactylon (L.) Pers. & Capillipedium hugelii (Hack.) Stapf. & $\begin{array}{l}\text { Sachoenefeldia } \\
\text { gracilis Kunth }\end{array}$ & $\begin{array}{l}\text { Imperata cylindrica } \\
\text { (L.) P. Beauv. }\end{array}$ \\
\hline 6 & $\begin{array}{l}\text { Dactyloctenium aegyptium } \\
\text { (L.) P. Beavu. }\end{array}$ & Cenchrus biflorus Roxb. & $\begin{array}{l}\text { Setaria verticillata } \\
\text { (L.) P. Beauv. }\end{array}$ & $\begin{array}{l}\text { Ophiuros exaltatus } \\
\text { (L.) O. Ktze. }\end{array}$ \\
\hline 7 & $\begin{array}{l}\text { Dicanthium annulatum } \\
\text { (Forsk.) Stapf }\end{array}$ & Cenchrus setigerus Vahl. & Sorghum halepense (L.) Pers. & \\
\hline 8 & $\begin{array}{l}\text { Dicanthium caricosum } \\
\text { (L.) A. Camus }\end{array}$ & Chionachne koenigii (Spr.) Thw. & $\begin{array}{l}\text { Sporobolus diander } \\
\text { (Retz.) P. Beauv. }\end{array}$ & \\
\hline 9 & Eleusine indica (L.) Fruct. & Chloris barbata $\mathrm{S}_{w}$ & $\begin{array}{l}\text { Sporobolus fertilis } \\
\text { (Steud.) Clayton }\end{array}$ & \\
\hline 10 & Hackelochloa granularis (L.) O. & Chloris virgata $\mathrm{Sw}_{\mathrm{w}}$ & $\begin{array}{l}\text { Sprobolus helvolus (Trin.) } \\
\text { Th. Dur. et Schinz }\end{array}$ & \\
\hline 11 & Ischaemum molle $\mathrm{Hk}$. f. & $\begin{array}{l}\text { Digitaria adscendens (H.B. } \\
\text { and K.) Henrard }\end{array}$ & $\begin{array}{l}\text { Sporobolus marginatus } \\
\text { Hochst.ex A. Rich. }\end{array}$ & \\
\hline 12 & $\begin{array}{l}\text { Ischaemum pilosum } \\
\text { (Klein ex Wild.) Wt. }\end{array}$ & $\begin{array}{l}\text { Digitaria granularis } \\
\text { (Trin. ex Spr.) Henr. }\end{array}$ & & \\
\hline 13 & Ischaemum rugosum Salisb. & Echinochloa colonum (L.) Link. & & \\
\hline 14 & Iseilema laxum Hack. & Echinochloa crusgalli (L.) P. Beauv. & & \\
\hline 15 & Paspalidium flavidum (Retz.) A. & Echinochloa stagnina (Retz.) P. Beavu. & & \\
\hline 16 & Paspalum scrobiculatum L. & Eragrostiella bifaria (Vahl) Bor & & \\
\hline 17 & $\begin{array}{l}\text { Pennisetum setosum } \\
\text { (Sw.) L. C. Rich. }\end{array}$ & $\begin{array}{l}\text { Eragrostis cilianensis (All.) } \\
\text { Link ex Vignolo-Lutati }\end{array}$ & & \\
\hline 18 & Sehima ischaemoides Forsk. & Eragrostis ciliaris (L.) R. Br. & & \\
\hline 19 & Sehima nervosum (Rottl.) Stapf & Eragrostis japonica (Thunb.) Trin & & \\
\hline 20 & $\begin{array}{l}\text { Sehima sulcatum } \\
\text { (Hack.) A. Camus }\end{array}$ & Eragrostis nutans (Retz.) Nees ex Steud. & & \\
\hline 21 & Sorghum bicolor (L.) Moench & $\begin{array}{l}\text { Eragrostis tenella }(\mathrm{L} .) \text { P. } \\
\text { Beauv. ex R. and S. }\end{array}$ & & \\
\hline 22 & $\begin{array}{c}\text { Themeda laxa (Anderess.) } \\
\text { A. Camus }\end{array}$ & $\begin{array}{l}\text { Eragrostis unioloides } \\
\text { (Retz.) Nees ex Steud. }\end{array}$ & & \\
\hline 23 & Themeda quadrivalvis (L.) Ketz. & Eragrostis viscosa (Retz.) Trin. & & \\
\hline 24 & Themeda triandra Forsk. & $\begin{array}{l}\text { Heteropogon contortus var. genuisus } \\
\text { subvar. Typicus } \\
\text { (L.) P. Beauv. }\end{array}$ & & \\
\hline 25 & & $\begin{array}{l}\text { Heteropogon contortus var. genuisus } \\
\text { subvar. Hispidissimus (L.) P. Beauv. }\end{array}$ & & \\
\hline 26 & & Isachne globosa (Thunb.) O. & & \\
\hline 27 & & Ischaemum indicum (Houtt.) Merrill & & \\
\hline 28 & & Panicum antidotale Retz. & & \\
\hline 29 & & Panicum trypheron Schult. & & \\
\hline 30 & & Perotis indica (L.) O. Ketz. & & \\
\hline 31 & & Setaria glauca (L.) P. Beauv. & & \\
\hline 32 & & Setaria tomentosa (Roxb.) Kunth & & \\
\hline 33 & & Thelepogn elegans Roth ex R. andS. & & \\
\hline 34 & & Themeda cymbaria (Roxb.) Hack. & & \\
\hline
\end{tabular}


Tab. 3. List of Palatable Legumes

\begin{tabular}{|c|c|c|}
\hline Sr. No. & Highly Palatable & Moderately Palatable \\
\hline 1 & Alysicarpus bulgaumensis Wt. & Crotolaria spectabilis Roth. \\
\hline 2 & Alysicarpus monilifer (L.) DC. & Goniogyna hirta (Willd.) Ali \\
\hline 3 & Alysicarpus procumbens (Roxb.) Schindl & Indigofera enneaphylla L. \\
\hline 4 & Alysicarpus tetragonolobus Edgew. & Indigofera tinctoria $\mathrm{L}$. \\
\hline 5 & Alysicarpus vaginalis (L.) DC. & Sesbania aculeata (Willd.) Pers. \\
\hline 6 & Atylosia scarabaeoides (L.) Benth. & Sesbania sesban (L.) Merr \\
\hline 7 & Cassia absus $\mathrm{L}$. & Tephrosia purpurea Pers. \\
\hline 8 & Cassia occidentalis $\mathrm{L}$. & Tephrosia villosa (L.) Pers. \\
\hline 9 & Cassia tora $\mathrm{L}$. & \\
\hline 10 & Clitoria ternatea $\mathrm{L}$. & \\
\hline 11 & Crotalaria albida Roth. & \\
\hline 12 & Crotalaria linifolia L. f. & \\
\hline 13 & Crotolaria burbia Benth. & \\
\hline 14 & Crotolaria calycina Schrank & \\
\hline 15 & Crotolaria filipes var. trichophora (Bth. ex. Baker) Cooke & \\
\hline 16 & Crotolaria juncea $\mathrm{L}$ & \\
\hline 17 & Crotolaria mysorensis Roth. & \\
\hline 18 & Crotolaria notonii W. and A. Prodr. & \\
\hline 19 & Crotolaria orixensis Rottler ex Willd. & \\
\hline 20 & Crotolaria retusa $\mathrm{L}$. & \\
\hline 21 & Indigofera cordifolia B.Heyne ex Roth. & \\
\hline 22 & Indigofera echinata Willd. & \\
\hline 23 & Indigofera glandulosa Wendl. & \\
\hline 24 & Indigofera linifolia (L.f.)Retz & \\
\hline 25 & Rhynchosia minima DC. & \\
\hline 26 & Zornia gibbosa Span. & \\
\hline
\end{tabular}

is less compared to the other villages coming under this range.

The availability of green fodder is the most important single factor responsible for the success of animal husbandry. With the intensification of livestock development the importance of fodder production is fully recognized. Natural grasslands play an important role in supplying fodder to the animals. But due to heavy grazing pressure productivity in some of the grasslands in the study area is very poor.

Most of the tribal in these areas are farmers and are almost completely dependent on the forest resources. The grasslands nearby these villages are in the custody of the forest department and so they work as labourers in these grasslands for harvesting these grasses. The main occupations of the villagers are to grow Zea mays and Paspalum scorbiculatum. Other than this the land nearby their huts are used for growing vegetables like Bringal, Lady's finger, Cucurbits etc. for their own household purposes. When the production of grasses in the grasslands is more than the requirement of the villagers, these are sold in the nearby markets.
Fodders from the forest form an important source for cattle and other grazing animals of these regions. There are many varieties of grasses, trees and shrubs that are nutritious for the live stock. Many of the grasses are helpful in soil conservation (Gould, 1968). A total of around 69 grasses and 34 legumes could be recorded from the study area. A list of the grasses and legumes collected from the study area and its palatability has been represented in Tab. 2 and 3. Among the collected grass species 27 species belonged to the tribe Andropogoneae, while other major tribes were Paniceae and Eragrosteae with 19 and 12 species respectively. The fodder value of these species and the most suitable palatable stage of these have been recorded in Tab. 2 and 3.

During the monsoon period, the growth of natural grasses is appreciable and plenty of grasses are available. Species like Dichanthium annulatum, Bothriochloa pertusa, Sehima nervosum, Sebima sulcatum, Chrysopogon fulvus are highly palatable grasses and are frequently used. Few grasses are considered to be palatable only at its vegetative phase (before the flowering appears). For example, Cymbopogon martini is considered palatable only in the vegeta- 
Tab. 4. List of plants which are used as food or medicinal purposes

\begin{tabular}{|c|c|c|c|c|c|}
\hline $\begin{array}{l}\text { Sr. } \\
\text { No. }\end{array}$ & Plant name & Family & Local Name & Used part & Uses \\
\hline \multicolumn{6}{|c|}{ As food } \\
\hline 1 & Cassia absus & Leguminosae & Saved & $\begin{array}{c}\text { Leaves at } \\
\text { vegetative stage }\end{array}$ & As vegetables \\
\hline 2 & Leucas aspera & Lamiaceae & & Leaves & As food \\
\hline \multirow{2}{*}{3} & \multirow{2}{*}{ Cassia tora } & \multirow{2}{*}{ Leguminosae } & \multirow{2}{*}{ Puvad } & Young leaves & As vegetable \\
\hline & & & & Flowers & For food \\
\hline 4 & Crotolaria albida & Leguminosae & Nano Gughro & Leaves & As food \\
\hline 5 & Cucumis callosus & Cucurbitaceae & Khachara & Leaves, dried ripe fruit & As food \\
\hline 6 & Paspalum scorbiculatum & Poaceae & Kodri & Seeds & As food \\
\hline 7 & Indigofera glandulosa & Leguminosae & Zinjaru & Seeds & As food \\
\hline 8 & Echinochloa colonum & Poaceae & Samo & Seeds & As food \\
\hline \multicolumn{6}{|c|}{ For medicine } \\
\hline \multirow{2}{*}{1} & \multirow{2}{*}{ Cassia occidentalis } & \multirow{2}{*}{ Leguminosae } & \multirow{2}{*}{ Puvad } & Root & Jaundice \\
\hline & & & & Seeds & As traditional medicine \\
\hline 2 & Coix lachryma-jobi & Poaceae & Kasai & Seeds & $\begin{array}{l}7 \text { seeds mixed with honey and } \\
\text { used as a medicine in Asthma. }\end{array}$ \\
\hline 3 & Butea monosperma & Leguminosae & Kesudo & Bark, flowers & Use in fractures \\
\hline 4 & Hemidesmus indicus & Apocynaceae & & Whole plant & $\begin{array}{l}\text { Used in polymorphs bite, in } \\
\text { dysentery and in diarrhoea. }\end{array}$ \\
\hline 5 & Solanum xanthocarphum & Solanaceae & Bhoy ringni & Seeds & $\begin{array}{l}\text { Fumes of seeds are use for the } \\
\text { treatment of teeth decay. }\end{array}$ \\
\hline 6 & Cassia absus & Leguminosae & Saved & Dry seeds powder & $\begin{array}{l}\text { Used for the treatment } \\
\text { of conjunctivitis. }\end{array}$ \\
\hline \multirow{2}{*}{7} & \multirow{2}{*}{ Rhynchosia minima } & \multirow{2}{*}{ Leguminosae } & & root paste & Used to cure joint pain. \\
\hline & & & & Leaves & For Achne. \\
\hline
\end{tabular}

tive and bud condition. In scarcity after drying these grasses are also used as fodder. Sorghum halepanse is an unpalatable grass and cattle never prefer them especially when it is in vegetative and flowering stage. According to Adivasi tribal people Sorghum halepanse is considered to be toxic during the vegetative and flowering period, but after the seed dispersal and drying this grass is eaten by cattle, especially in a scarcity period. Ophiorus exaltatus is an unpalatable grass, having allelopathic effect on other plants. This species occurs especially where soil is black and sticky.

It is a tradition of the villagers in this region that the first cutting of the grass is done after monsoon period irrespective of whether the grass is fully mature or flowering, seed dispersal. When the monsoon season is over, the grasses from the grassland is harvested even before fully drying and is stored as hay by the forest department. These grasses are baled and stored in the store house of the forest department.

The tribal people of the villages are dependant on grasslands for the fodder and on forest area for the live hood products. The tribal people of Kantu collect wood from the forest mainly to prepare farming implements like plough and for fuel.

The tribals, store the grass species by preparing a bale at their homes. They collected grasses from the grasslands.
But the tribals of Kantu and Bhey, collect grasses from forest and from surrounding of their farming area because in these villages no such type grasslands are present.

During summer, the tribal people purchase grasses in form of Gansadi, which weighs around $50 \mathrm{~kg} /$ gansadi paying around 1000-1200 Rs. each. At the time of scarcity fodder is purchased from Government quota.

Other than the fodder various other uses of the plant species could also be documented. Sometimes the tribal people use Cymbopogon martinii species after drying, to make "Kachcha Ghar" i.e. as the base material for temporary huts. Desmostachya bipinnata is used during the death of a person for preparing the funeral bed while Cynodon dactylon is used for worship. Seeds of Heteropogon contortus are used to kill crow. The tribal people make chapattis (bread) which are made by using powdered seed flour to keep the crows away from the food items carried by them to eat in the field during their work. This species is also palatable except when it is in flowering and fruiting condition. Leaves of Madhuca indica are use to make a bowl for tea. Flowers and fruits are also used for brewery by distillation process. During the flowering season fruits of Madhuca are used in fermentation for liquor preparation and sold in nearly markets. They extract oil from the flower and are sold in the market. Seeds of Coix lachryma-jobi and Chion- 

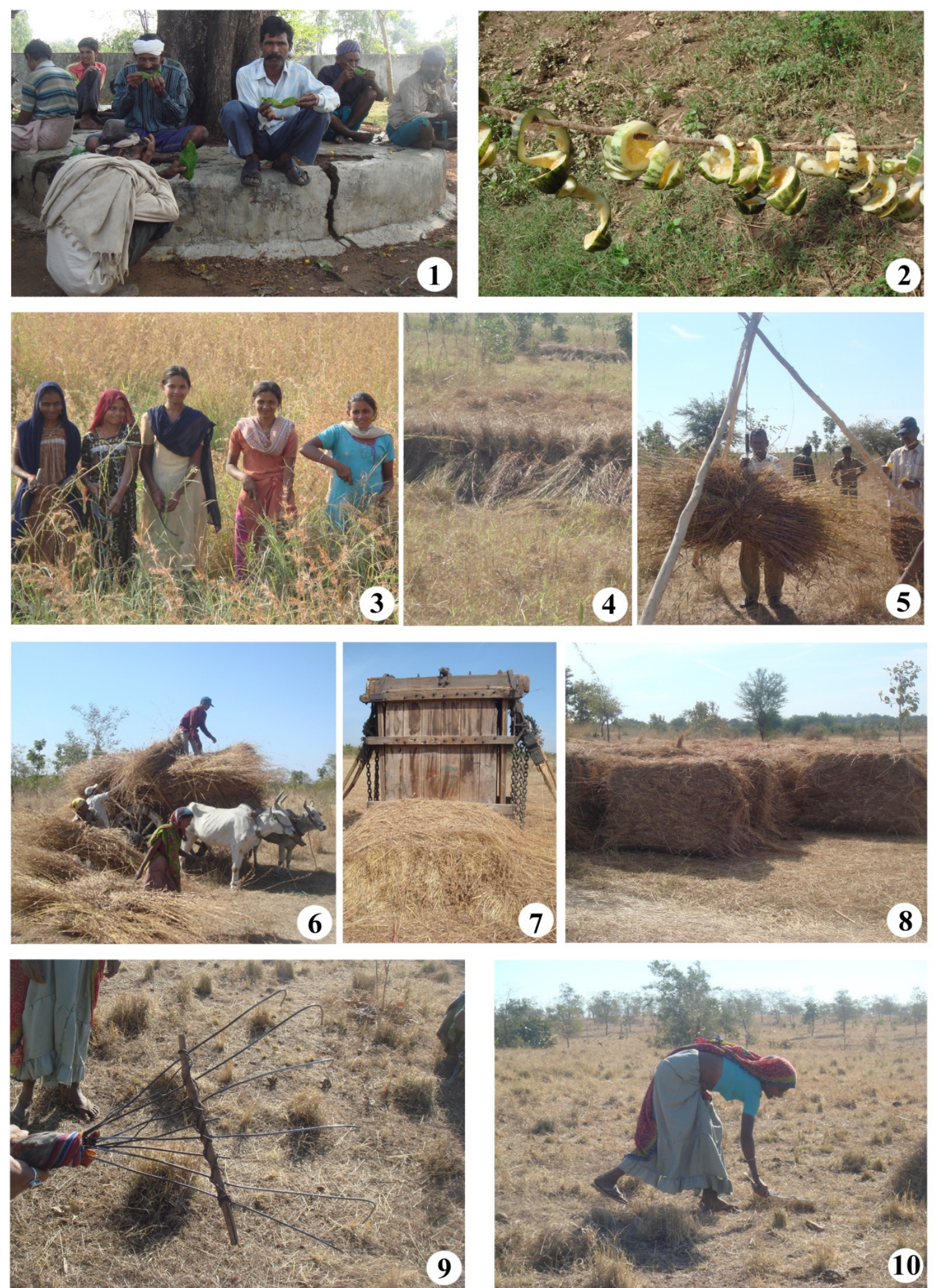

Fig. 2. Tribals of the villages and their activities

1. Tribal people of Kantu using leaves of Madhuca indica as bowl; 2. Drying of cucurbits on ropes; 3. Tribal people of Rampura cutting grasses; 4. Storing of gansdi (baled grass); 5. Forest officials weighing gansdi; 6. Transportation of gansdi by bullock cart; 7. Pressing machine to bale the grasses; 8 . Baled grasses stored; 9 . Handmade equipment used for collection of grasses; 10 . Tribal people collecting grasses 
achne koenigii are used for making jewellery. Other than these plants few plants are specially used for food as well as for medicinal purposes, which are listed in Tab. 4 .

\section{Conclusions}

The present investigation revealed the significance of grass and legume species used by the tribals and villages of Baria and Godhra forest divisions. The present findings will contribute to understand the community structure, composition of wild species of grasses and legumes in these grasslands. The study will also emphasize the use of plant wealth to human needs of the regions and assist in appraisal of various anthropogenic interventions accountable for loss of prevailing biodiversity of the region. The collective efforts of ethanobotanists, phytochemists, pharmcognosists and pharmacologists are needed to document and evaluate the efficacy and safety of the claims. The indigenous knowledge and uses of the plants of a particular area have to be analyzed to develop appropriate management measures (ex situ and in situ conservation) for best utilization of natural resource.

\section{Acknowledgments}

Authors are thankful to the working Plan Circle, Forest Department, Vadodara, Gujarat state for providing the financial support.

\section{References}

Agrawal A (2002). Indigenous knowledge and politics of classification. Internat Soc Sci J 54:287-297.

Agrawal JP (2001). GEER, National Biodiversity Strategy Action Plan (NBSAP): A Sub-State Action Plan for Gujarat State (Gujarat State Forest Department, Gandhinagar, India).

Ahmad F, Mir AK, Ahmad M, Zafar M, Nazir A, Sarfraz KM (2009). Taxonomic studies of grasses and their indigenous uses in the salt range area of Pakistan. Afr J Biotechnol 8(2):231-249.

Blatter E, McCann C (1936). The Bombay Grasses. Manager of publication. Delhi.
Clayton WS, Renvoize G (1986). Genera Graminum, grasses of the world. Kew Bull Addit Series 13:1-389.

Cook T (1903). The flora of the presidency of Bombay. Taylor and Francis, London. Vol. I and II.

Cope TA, Poaceae D (1982). No 143. In: Nasir E, Ali Sl (Eds.). Flora of Pakistan. National herbarium Pakistan Agriculture Research Council, Islamabad.

Dabadghao I, Shankamarayanan A (1973). The grass cover of India. ICAR, New Delhi, p. 713.

FAO (1999). State of the World's Forests.

Gandhi D, Susy A, Pandya N, Panchal K (2010). Vegetational diversity in the land of Bhey (Garbada). Biosci Repor $8(1): 45-50$.

Good R (1953). The geography of the flowering plants. $2^{\text {nd }}$ ed. Longmas, Green and Co, Ltd. London.

Gould FW (1968). Grass Systematics. Mc Graw-HillBook Company. New York.

Gopal GV (1983). Ethnobotanical studies in the forest areas of some parts of Gujarat, PhD Thesis. Gujarat University, Ahmedabad.

Mishra PC, Tripathy PK, Behera N, Mishra K (2008). Socioeconomic and socioecological study of sambhalpur forest division, Orissa. J Hum Ecol 23(2):135-146.

Olsson P, Folke C, Berkers F (2004). Adaptive co-management for building resilience in social-ecological system. Environ Manag 34(1):75-90.

Parabia MH, Yadav SS, Shah GL (1978). Phytological studies on the vegetation of Chhotaudepur forest of eastern Gujarat. Indian J of Forest 1:312-318.

Reddy AR (1986). Flora of Dharampur forest, $\mathrm{PhD}$ Thesis. Sardar Patel University, Vallabh Vidhyanagar, Gujarat.

Shah GL (1978). Flora of Gujarat State. Sardar Patel University of Gujarat. Vol. I and II.

Sillitoe P (1998). The development of indigenous knowledge. Curr Anthropol39:223-252.

Tyagi SN, Padhiar A, Susy A, Pandya N, Gandhi D, Panchal K (2010). Pictorial Floristic Diversity of Grasses and Associated Vegetation from Three Grasslands of Randhikpur Forest Range, Dahod, Gujarat. The Ind Forester 136:1581-1592. 